\title{
Sovyet Animasyon Tarihine Genel Bir Bakış ${ }^{1}$
}

\author{
Koray SEVINDI ${ }^{2}$
}

\section{$\ddot{O} z$}

Sovyet sineması daha çok propaganda amaçlı üretilen kurmaca ve belgesel filmleriyle bilinse de önemli bir animasyon ekolüne sahiptir. Sovyet animasyonları 1900'lü yılların başından itibaren ortaya çıkmaya başlamış, propaganda amaçlı üretilen animasyonların yanında halk hikâyelerine, masallara, efsanelere, eğitim ve öğretim faaliyetlerine, eğlenceye, mizaha, bilim kurgu ve fantastik anlatılara değinen yüzlerce animasyon da üretilmiştir. Türkçe literatürde Sovyet animasyonlarına yönelik çok az çalışma olmasından dolayı alana katkı sağlamak amacıyla bu çalışma oluşturulmuş, ağırlıklı olarak Rusça ve İngilizce kaynaklar derlenmiş, içerikler incelenmiş, bu kaynaklar üzerinden Sovyet animasyonlarına genel bir bakış oluşturularak betimleyici bir analiz yapılmıştır. Sovyetlerin sinemayla ilişkisinin ve bağının anlatıldığı ilk kısmın ardından Sovyet animasyonlarının 1900’lerin başındaki ilk örneklerinden Sovyetler Birliği’nin yıkılışına kadarki döneme kadar olan filmler incelenmiştir. Makalenin amaçlarından biri de bu alanda çalışmak isteyen akademisyenleri teşvik ederek onlara yardımcı olacak genel bir tarihsel anlatı sunmak ve yardımcı bir literatür özeti oluşturmaktır.

Anabtar Kelimeler: Sovyetler Birliği, Animasyon, Sinema, Betimleyici Analiz

\section{An Overview of Soviet Animation History}

\begin{abstract}
Although Soviet cinema is principally recognized for fiction and documentary films produced for propaganda goals, it has a significant animation ecole. Soviet animated films started to emerge from the beginning 1900s; in addition to the animations produced for propaganda plans, hundreds of animations, including folk tales, fairy tales, myths, educational activities, entertainment, humor, science fiction, and fantastic narratives, were also created. Since there is very few research on Soviet animations in Turkish literature, this study was designed to contribute to the field. Mainly Russian and English sources were compiled, the contents were examined, and a descriptive analysis was made by building an overview of Soviet animations through these references. After the first part of the relationship and connection of the Soviets with cinema, films from the earliest instances of Soviet animations in the early 1900 s to the destruction of the Soviet Union were analyzed. One of the article's objects is to present a comprehensive historical narrative to support academics wishing to work in this field and found a helpful literature summary.
\end{abstract}

Key Words: The Soviet Union, Animation, Cinema, Descriptive Analysis

\section{Atıf İçin / Please Cite As:}

Sevindi, K. (2021). Sovyet Animasyon Tarihine Genel Bir Bakış. Manas Sosyal Araştırmalar Dergisi, $10(3), 1771$ 1784.

Geliş Tarihi / Received Date: 14.02.2021

Kabul Tarihi / Accepted Date: 23.03.2021

\footnotetext{
${ }^{1}$ Bu makale Koray Sevindi tarafından Marmara Üniversitesi Sosyal Bilimler Enstitüsü Sinema Bilim Dalı kapsamında hazırlanan "Sovyet Propaganda Animasyonlarında İdeolojik Söylem” doktora tezi çalısmasından türetilmiştir.

2 Arş. Gör. Dr. - İstanbul Medeniyet Üniversitesi, Sanat Tasarım ve Mimarlık Fakültesi, koray.sevindi@medeniyet.edu.tr

iD ORCID: 0000-0003-0264-5390
} 


\section{Giriş}

Sinema, ilk ortaya çlktığı andan itibaren tüketim kültürüne olan yatkınlığ1 ve düşünceleri aktarma konusunda sahip olduğu geniş imkânları sayesinde gittikçe artan bir popülarite kazanmıştır. Görsel iletinin sahip olduğu gerçeklik hissi, duygulara ve bilinçaltına yönelik anlatımlarla kişiler üzerinde kanı oluşturma ve aktarılan fikirleri kökleştirme becerisi, sinemayı özellikle Birinci Dünya Savaşı sonrasındaki totaliter rejimler tarafından önemli bir siyasal propaganda aracı konumuna getirir. Güçlü bir kitle iletişim aracı olarak sahip olduğu manipülatif yapı, temas ettiği kişileri yönlendirme, bilinçlendirme ve vicdani açıdan rahatlatma özelliğine sahiptir. Bu yönüyle devlet eliyle yapıldığında sinemanın mevcut politikanın halkın gözünde normalleştirilmesini sağlama gücü olduğu da söylenebilir. Bu şekilde propaganda, toplumların kendi iç dinamiklerini güçlendirme ve halk arasında bir birlik bilinci oluşturma amacıyla kullanılma gibi düşmanı zayıflatma ve ona karşı bir tepki oluşturma amacıyla da kullanılabilir. Kendi ülke sınırlarında daha belirgin ve açık kaynaklı bir şekilde yapılan bu propaganda, başka ülkelerin sahasına girdiğinde daha dolaylı hale gelerek kendisini gizlemeye de çalışır.

Propaganda sineması denilince Sovyetler Birliği ilk akla gelen ülkelerden biridir. Propagandayı devlet eliyle yapan ve bunu uzun yıllar sürdürebilen bu ülkede siyasal fikirlerin ve ideolojilerin gelişmesi ve kalıc1 olması sinemaya çok şey borçludur. Fakat Sovyet sineması daha çok propaganda amaçlı üretilen kurmaca ve belgesel filmleriyle bilinse de önemli bir animasyon ekolüne de sahiptir. Sovyet animasyonları 1900'lü yılların başından itibaren ortaya çıkmaya başlamış, propaganda amaçlı üretilen animasyonların yanında halk hikâyelerine, masallara, efsanelere, eğitim ve ögretim faaliyetlerine, eğlenceye, mizaha, bilim kurgu ve fantastik anlatılara değinen yüzlerce animasyon da üretilmiştir. İlk propaganda animasyon çalışmaları da diğer türlerle paralel olarak- 1920'li yılların başında başlamıştır. Animasyonlara yönelik bu ilgisizliğin nedenleri olarak; filmlerin ilk yıllarda farklı gruplar tarafindan düzensiz bir şekilde üretilmesi, Soyuzmultfilm adında farklı bir stüdyoda üretim ve arşivleme yapılması, filmlerin arşivlerinin ve bilgilerinin düzenli bir şekilde tutulmaması, filmlerin çoğunun uzun soluklu olarak değil dönemlik etkiler ve işlevsel kaygilar için üretilmesi, hedef kitle olarak sadece kendi toplumunu seçmesi, çeşitli tarihsel olaylar nedeniyle arşivlerin taşınması ya da yok olması, tarihsel olaylara yönelik yapılan çalışmaların günlük siyaset akışında güncelliğini yitirmesi ya da tehlikeli bir materyale dönüşmesi gibi pek çok neden sayılabilir. Tabi buna animasyonların çocuklar için üretilen basit filmler olduğu ön yargisı da eklenebilir. Nitekim Sovyet animasyonlarının çoğundan ancak Sovyetler Birliğ̣’’nin dağılmasıyla birlikte arşivler açllnnca haberdar olunur ve filmlere 1990'lı yılların sonlarına doğru çıarılan DVD’ler sayesinde ulaşılmaya başlanır. Sovyetler Birliği'nin aktif olduğu dönem boyunca üretilen 1400'e yakın filmin bu kadar kısa süre önce ortaya çıkarılması ve üzerine bu kadar az çalışma yapılmış olması bu çalışmasının çıkış noktalarından biri olmuştur.

Filmler anlattığı dönemi yansıtan belgelerdir ve ortaya çıktıkları toplumda bir bellek ve kültürel hafıza oluştururlar. Bu nedenle neredeyse Sovyetler Birliği’yle aynı yaşta olan Sovyet animasyon sineması önemli bir kültürel hafiza olarak görülebilir. Hatta kurmaca ve belgesele göre daha kapsamlı bir bellek olduğu bile söylenebilir, çünkü animasyon anlatısı hem doğrudan bilgi sağlayabilen, hem hikâye anlatabilen, hem hayal gücünü daha kolay yansıtma olanağı veren ve hem de sahip olduğu biçimsel olanaklar nedeniyle simgesel anlatıma çok daha uygun olan bir türdür. İkonaların kullanımı, Rus avangardı, illüstratif posterlerin yaygınlığı, kukla sanatının gelişmesi gibi nedenlerin de animasyonun çalışma alanını ve kabul edilebilirliğini Sovyetler Birliği’nde güçlendirdiği söylenebilir. Bu nedenle sadece somut olayların değil soyut fikirlerin ve zihinsel etkilerin yansitılmasına da animasyon diğer türlere göre daha fazla imkân verir. Ayrıca, sosyalist gerçekçiliğin etkin olduğu Stalin döneminde propaganda unsuru olarak -yapı itibarıla- gerçekçi zeminden oldukça uzak olan animasyonların kullanılması da kendi başına bir çelişki barındııır.

Çalışmada, Türkçe literatürde Sovyet animasyonlarına yönelik neredeyse hiç kaynak olmamasından dolayı alana katkı sağlamak amacıyla ağıllkklı olarak Rusça ve İngilizce kaynaklar derlenmiş, içerikler incelenmiş, bu kaynaklar üzerinden genel bir bakış oluşturularak betimleyici bir analiz yapılmıştır. İlk kısımda Sovyetler Birliğiłyle sinemanın ilişkisine değinilmiş, ikinci kısımda da Sovyet animasyon tarihine genel bir bakış oluşturulmuştur. Makalenin amaçlarından biri de bu alanda çalışmak isteyen akademisyenleri teşvik ederek onlara yardımcı olacak bir literatür özeti sunmaktır. Nitekim gerek Rusça'da gerekse İngilizce'de Sovyet animasyonları üzerine yapılan çalışmalar oldukça yenidir ve bilimsel araştırmaya açıtır. 


\section{Sovyetler Birliği, Propaganda ve Sinema İlişkisi}

Sovyetler Birliği'nde yönetim, rejimin prensiplerini halka ulaştırmak için kullanabileceği her aracı ve detayı kullanır. Bu yapılanmada ve ideolojinin gelecek nesillere aktarılmasında çeşitli teşkilatlar kurulur. Ağırlıklı olarak çocuklara ve gençlere yönelik yapılan bu çalışmalar okullarda, orduda, çalışma hayatında ve evlerde birbirini tamamlayan faaliyetler olarak uygulanır. Dergi, gazete ve broşürlere ağırllk verilir ve Sovyet medya sistemi geliştirilir. Sovyetler Birliği’nde on tip basın türü vardır ve bunlar partiye, sendikaya, orduya, köylülere ve gençlere yönelik olanlarla diğer yayınlar olarak kullanılır. Sovyet gazetelerinin tirajı çok hızlı bir şekilde artar ve yüzbinlerce kopyaya ulaşır. 1921'de Devlet Gazetecilik Enstitüsü oluşturulur ve basın için profesyonel personel yetiştirilmeye başlanır (Polyakov, 1967, s. 653 Akt: Georgievna, 2013, s. 182).

Sovyet yönetimi 1920 'ler ve 1930'lar periyodunda edebiyatın ve sanatın yönetimine de büyük önem verir. Yaklaşık kırk beş bin yazar, gazeteci ve editör; yüz binden fazla kültür, siyaset ve eğitim personeli ile on binlerce sanatçı propaganda aktivitelerine katılması için çağrilır (Nevezhin, 2007 Akt: Georgievna, 2013, s. 182). Sözlü ajitasyon ve propaganda çalışmalarının organize edilmesi için özel bir çaba harcanır ve 1930’ların sonunda yüz on iki binden fazla insan sözlü propaganda çalışmalarına katılır. "Her Bolşevik Bir Ajitatördür" kullanılan ilk sloganlardan biridir. Sıradan parti üyelerinin, Komsomol üyelerinin ve parti dışı aktivistlerin kurduğu propaganda ordusu, insanları sadece sözle değil kişisel ilişkiler üzerinden de ikna etmesi için seçilir. Bu nedenle kendisi için belirlenen bölgedeki insanların kişisel ihtiyaçlarından ve sorunlarından, ayrıca çalıştığı fabrikadaki ya da kolektif çiftlikteki şartlardan da haberdar olması beklenir (Georgievna, 2013, s. 182).

Sovyetler Birliği’nde propaganda kavramı üç şekilde kullanılmıştır: insanların dünya görüşünü geliştirmek için fikir, değer ve bilgi yaymak (bilgilendirme propagandası); devletlerin ideolojilerini ve ilkelerini açıklamak (siyasi propaganda); devlet karşıtı ya da komünizm karşıtı burjuva propagandasına karşı mücadele etmek (karşı propaganda). Bilgilendirme propagandasında gazete, dergi vb. kitle iletişim araçları vasıtasıyla Sovyet toplumuna otoritelerin bakış açısından bazı fikirler ve konular sunulur. Siyasi propagandada devletin ve partinin hem ülkedeki hem de uluslararası arenadaki faaliyetlerinin bütün detayları konuşmacilar tarafından Sovyet halkına aktarılır. Konuşmacılar, sosyalist ideolojiyi ve siyasi yönelimi sağlamaya yönelik olan bu faaliyetlerini çeşitli işletmelerde, eğitim kurumlarında, kültürel kuruluşlarda, çiftliklerde, sanayi ve teknik okullarda gerçekleştirir. Karşı propaganda ise komünist propagandanın etkisini korumaya çalışan, kapitalist ülkelerin görüşlerinin ve faaliyetlerinin engellendiği, kapitalizmin "çürümesine" ve burjuva ülkelerinin -hem kendi halklarına hem de diğer ülkelerdekilere karş1suçlarına odaklanan bir çizgide ilerler (Lozhkov, 2013, s. 189-190).

Kitleleri hem eğiten hem de mevcut siyasal düşün yapısını kazandıran propaganda çalışmalarında sanat ise, devlet eliyle yürütülen, sosyalist yapı için verilen savaşta ve sınıf çatışmasının ön saflarında kullanılan bir araç olarak görülür. Toplumsal amaçlara ve isteklere yanıt verir. Eisenstein'in de belirttiği gibi devlet nezdinde sanatın metalürji biliminden bir fark1 yoktur (1982, s. 25). Bu nedenle filmlerde de Sovyet halkına içinde bulundukları siyasi ortamı tanıtmak ve karşıt güçleri kötüleyerek var olan devlet otoritesini korumaya almak birincil amaçtır. Burada sinemanın evrensel yapısı, kolaylıkla taşınabilir ve çoğaltılabilir olması, dil sorununu ortadan kaldıran görsel gücü ve okuma yazma bilmeyen halka bile istenilenin aktarılabilmesini sağlaması önemli özellikleridir.

Lenin için sinemadan yararlanma sorunu devrimin zafer kazanmasından ve sosyalizmin uygulanmaya başlamasından sonra özel bir önem kazanır. Sinema kitlelere nüfuz etme konusunda çok başarılıdır ve bunun farkında olan Lenin, filmleri emekçi kitlelerin sosyalist eğitimi için kullanmak ister. Sinemanın izleyiciyi siyasal yaşamdan ve güncel sorunlardan uzaklaştıran "burjuva zevki" filmlerden arındırılması gerektiğini söyler. Böylece sinema, Komünist Parti’nin programında işçilerin ve köylülerin eğitilmesi ve geliştirilmesi için kullanılacak olan araçlardan -kütüphaneler, okullar, üniversiteler, konferanslar vb.- biri olarak gösterilir. Sinema, propaganda amacıyla kullanıldığından dolayı belli kurallar çerçevesinde kullanılır; çünkü propagandanın ters amaçlar için kullanılmasının önüne geçilmek istenir. Bu nedenle Lenin, sinemanın deneyimli Marksistlerin ve edebiyatçların yer aldığı bir denetleme mekanizmasına tabi olması gerektiğini söyler (Karaganov, 2009, s. 82-85).

Sinemadaki iktidar mücadelesi aslında sinema işçilerinin mesleki örgütleri olan OKO (dağıtımcıların, gösterimcilerin ve yapımcıların bir federasyonu), Sinema Sanatı İşçileri Birliği (yaratıcı işçiler-"sinema aristokrasisi”) ve çoğunlukla projeksiyoncu proletaryadan oluşan Sinema-Tiyatro İşçileri Birliği vasıtasıyla 
1917'de başlar; fakat Sovyet sineması, fotoğrafik ticaretin ve endüstrinin Halk Eğitim Komiserliği’ne (Narkompros) devri hakkındaki kararnamenin Lenin tarafindan imzalandığ 27 Ağustos 1919 tarihinde resmi olarak doğar (Nussinova, 1996, s. 162). Halk Eğitim Komiserliği tarafindan 1919 yllında yayınlanan "Sinematograf" derlemesinde "burjuva" sinemasının toplumsal rolü üzerine pek çok tespit yer alır. Sinemanın süslenmiş ve basitleştirilmiş yöntemlerle seyircilerin beyinlerini ve kalplerini yozlaştırdığını anlatan bu yazı, sinemanın sadece zihinleri ve ahlakı köreltmekle kalmadığını, kitleleri bencil ve pasif bir duruma getirdiğini, böylece sömürücü ve köleleştiren sınıfa da hizmet ettiğini söyler. Sinemanın eğiten ve kitleleri aydınlatan tarafını ön plana çıkararak kendisine yüklenen görevlerin altından kalkabileceğini, bunu yaparken de sinemacıların ortak ve enerjik bir çaba göstererek sinemayı gerçek bir sanat haline getirmeleri gerektiğini anlatır. Sergei Eisenstein, Vsevolod Pudovkin, Alexander Dovzhenko gibi isimler bu ilkeler çerçevesinde gelişen Sovyet sineması içinde gelişmişlerdir. Bu nedenle, 1920'li ylllarda devrimci sinemanın gelişimi ve yükselişi Leninizmin etkisine, öğretisine, bilimsel buluşlarına ve devrimci halkın toplumsal pratiğinin keşiflerine dayanır (Karaganov, 2009, s. 89-91). Bunun yanında devrim öncesi sinemasını bir miras olarak gören ve korumaya çalışan bir grup da vardır. Bu sinemacılar ülkelerinden göçmek zorunda kalarak başta Avrupa'nın çeşitli şehirleri olmak üzere Hollywood'a kadar uzanan zorunlu bir yolculuğa çıkarak gittikleri ülkelerde tutunmaya çalışır (Nussinova, 1996, s. 198-199).

Paul Rotha, dönemin Sovyet sinema filmlerinin eğitici ve bilinçlendirici bir misyon üstlendiğini ve bu filmlerin üretim amaçları doğrultusunda bazı sınıflara ayrılabileceğini belirtir. İlk sınıfta Devrim öncesindeki ve sonrasındaki hayata yönelik genel konuların ele alındığı filmler vardır. Dram, komedi, melodram vb. türlerdeki bu filmler, Çar dönemindeki zorlukları ve zulümleri göstererek Sovyet döneminin kazanımlarını ön plana çıkarmayı amaçlar. İkinci sınıftaki filmler hükümet destekli eğitimsel, bilimsel ve kültürel filmleri de içine alan yapımlardır. Öğretici filmler, endüstri, tıp, coğrafya gibi alanlarda olabildiği gibi mühendisler ya da ordu çalışanlarına yönelik mesleki filmler de olabilir. Üçüncü sınıfta haftanın olaylarının anlatıldığı ve ülkedeki lideri popülerleştirme amacı taşıyan haber filmleri gelir. Son sınıfta ise çocuk filmleri vardır. Hükümet tarafindan her bir sınıf için senaryo grupları ve bilgi büroları kurulur. Merkez büronun kontrolü altında sürdürülen bu çalışmalar mevcut hükümetin çizgisiyle paralel ilerlemek ve hükümetle uyum içinde çalışmak zorundadır (1930, s. 149-150).

Troçki, sosyalizmin ancak belli bir kültür seviyesinin üzerine inşa edilebileceğini ve bu nedenle işçi sınıfinın kültür seviyesinin yükseltilmesi gerektiğini söyler. Zaten devrimle birlikte kültür seviyesinin düşüklüğünden gelen bir utanç ve buna bağlı olarak bir kendini geliştirme arzusu söz konusudur. Troçki, işçiler arasındaki bu kültür açlığını devrimin en büyük başarılarından biri olarak görür (Trotsky, 1986, s. 163). Sinema bu kültürel gelişim için önemli bir araçtır. Troçki, sinemayı -daha önce halkı uyutmak için kullanılan- dinin ve içkinin rakibi olarak öne sürer. "Anlamsız" dini ritüellerin sadece eleştiri yoluyla ortadan kaldırılamayacağını, sinemanın eğlendirici, eğitici ve hayal gücünü uyandıran yapısının insanları kilisenin kapısından uzak tutacağını ve bu nedenle sinemaya ne pahasına olursa olsun sahip çıkılması gerektiğini dile getirir (Trotsky, 1986, s. 33). Sinemanın bu şekilde kullanılması Stalin döneminde yoğun bir şekilde artar ve bu gücün farkına varan Hitler ve Mussolini gibi diğer devlet adamları da benzer uygulamaları hayata geçirir.

Agitka türü, Sovyet filminin stilistik gelişimi üzerinde belirleyici bir etkiye sahiptir. Malzemenin görsel sunumundaki ekonominin ve dinamizmin temeli kurgu prensiplerinde gelişir. Eisenstein daha sonra buna "dinamik montaj" der. Agitka, mesajını tamamen basit ve görsel yollarla iletmek zorundadır; çünkü seyircinin ilgisini çekmeli, onlarda dinamizm ve güç izlenimi bırakmalıdır. Bu ilkeler, Kuleshov'un teorik öğretilerinde ve Film Okulu atölyesinde; Vertov'un Sine-Göz (Kinoglaz) grubunun manifestosunda ve belgesellerinde; Shub, Eisenstein, Pudovkin ve diğerlerinin filmlerinde farklı yollarla somutlaşmıştır (Taylor, 1979, s. 56). Sovyet montaj yönetmenlerinin propagandanın ne olduğu ve neyi başarabildiği üzerindeki anlayışları Batı'dakinden çok daha zengindir. Kültürel ve tarihsel nedenlerden ötürü Sovyetler Birliği'nde propaganda, Batı'da olan ve hala devam eden olumsuz ahlaki ve politik çağrışımları yaratmaz. Sovyet otoritelerinin ve özellikle Marksist dünya görüşüne sahip olan pek çok Sovyet sanatçının Eisenstein, Pudovkin, Vertov gibi- propagandayla ilgili görüşü pozitiftir. Onlar propagandayı yeni Sovyet toplumunun inşasında katkıda bulunabilecekleri temel ve yapıcı bir parça olarak görür (Russell, 2009, s. 65). Fakat zamanla otoritelerle sanatçılar arasında propagandanın uygulanışı açısından bazı ayrımlar çıkar ve Stalin dönemiyle birlikte sanatçılar sansürle ve devlet baskısıyla uğraşmak zorunda kalır.

1922 yılının başlarında Lenin, gişe gelirlerini arttırmak ve Sovyet film endüstrisini gelecek dönemde finanse edebilmek amacıyla çok sayıda yabancı film ithal etmeye karar verir. Böylece eğlenceli, müstehcen ya da karşı devrimci olmayan, popüler ve ticari yabancı filmler gösterilir; fakat bu gösterimler sırasında bir 
tane kısa eğitim ya da propaganda filmi gösterilme şartı konur. Lenin, kitleleri sinemaya çekecek olan şeyin sinema olduğunu; fakat akılda kalacak olanın ise eğitim filmleri olacağını düşündüğü için yabancı film gösterimlerine çok aldırış etmez (Reeves, 1999, s. 62). Sovyetler Birliği, sonraki ylllarda -Amerikan filmleri de dâhil olmak üzere- film ithal etmeye ve yabancı üslupları taklit etmeye devam eder. 1920'lerin ortalarından itibaren ise kompozisyona ve montaja dayalı -ülke içinde pek karşıllk bulamasa da ülke dışında etkili olan- bir "Rus üslubu" gelişir. Stalinist rejimin güçlenmesi ve sinemaya diyalogun gelmesi ise montaj sinemasını sekteye uğratarak yerine Sosyalist Gerçekçilik üslubunu getirir. Yabanc1 film ithalatı durur ve aykırı düşünceler bastırılmaya başlanır (Nowell-Smith, 1996, s. 334).

Sansürün artmasıyla birlikte film üretmek de gittikçe zorlaşır. Stalin, 1930’lu yılların sonundan öldüğü tarih olan 1953'e kadar baş sansürcü olarak üretilen bütün filmleri izler, film isimlerine müdahale eder, senaryoları inceler, gözde yönetmen ve oyuncuları destekler. Sinemayı tamamen kontrolü altına alır. Yönetmen, Stalin'e göre senaryodaki talimatları uygulayan bir teknisyendir. Bu dar bakış açısı nedeniyle dönemin pek çok sinemacısı sinemadan uzaklaşır (Kenez, 1996, s. 392-393). Örneğin Eisenstein, Sosyalist devrimin yanında olmasına ve filmlerini de bu doğrultuda oluşturmasına rağmen, yapmaya çalıştı̆̆ sinemayı salt bir propaganda aracına dönüştürmeyi reddeder. Doğrudan parti sözcülügü yapan filmler yerine halkta devrimci düşünceler oluşturabilecek, sanatın biçimlerini ve yöntemlerini de kullanabilecek çalışmalar üretilmesi gerektiğini dile getirir. Bu nedenle Sovyet otoriteleriyle ters düsser (Vincenti, 1993, s. 39). Kendisinden istenen, sanatı ikinci plana atan ve onu ideolojik bir aygıt olarak gören çalışmalar üretmesidir; fakat o sanatsal kaygilardan ödün vermek istemez.

Sovyet sinemas1, 1920’lerin başında kazandığ1 ünü zamanla kısa sürede kaybeder. Sesin sinemada kullanımının bu gerilemede büyük payı olsa da asıl önemli neden Rusya'da 1930'larla birlikte başlayan siyasi değişimlerdir. Hükümet, yoğun sanatsal temelli, ticari olarak başarılı ve siyasi anlamda "doğru" filmler üretilmesini ister; fakat zamanla pratikte bu üçayağın da olduğu filmler üretmenin mümkün olmadığ1 anlaşılır. Böylece filmin başarısı ve halk tarafindan benimsenmesi birincil öncelik olurken diğer sanatsal ve deneysel çalışmalar "kusurlu” görülür. Stalin'in "Kültür Devrimi”yle birlikte sanatçıların belli ilkeler ve kalıplar içinde üretim yapması dikte edilir. 1934 yılında Sosyalist Gerçekçilik akımının devletin resmi sanat uygulaması olarak ilan edilmesi de bu dönemin bir sonucudur. Böylece sanatçıların devlet düzeninin dışında hayatlarını sürdürmesi ve eser üretmesi imkânsız hale gelir (Kenez, 1996, s. 389).

Sosyalist Gerçekçilik, sadece bir takım sanatsal kurallar olarak değil aynı zamanda bir ideoloji olarak ortaya çıkar. Bu sanatsal ilkelere bağlı olan kişiler sosyal ve politik hayatın getirdiği fikirlere de bağlılık gösterir. Hem sanatın hem de gerçekliğin resmi anlayışı Sosyalist Gerçekçilik’in üç ilkesiyle ortaya çıar: partizanlık (partiinost), ulusçuluk (narodnost) ve sinıfçllk (klassovost). Partizanlıkta, tüm deneyimler Komünist Parti düşüncesinin filtresinden geçirilir ve bu deneyimlerin Parti düşüncesiyle uyumuna bakıllır. Parti'nin dışında sanat var olamaz. Bu nedenle, sanatın Parti doktrinin reklamını yapması kaçınılmaz olur. Sosyalist Gerçekçilik; Parti, ulus ve sınıf üçgeninde, fabrikasyon bir ulusal birliğin özünü temsil eder (Paletz, 2001, s. 569). İşçilere, köylülere ve "sıradan" insana hitap etmeyen sanatın etkisiz ve "kusurlu" olduğu inancının bir yansıması olarak doğar.

Sosyalist Gerçekçilik, sanatsal anlayışı yönlendirmek için üç prensip ortaya koyarken, sanatı da zamanla iç içe geçmiş üç ilişki ile değerlendirir. İlkinde, sanatçı yalnızca modern Komünist devlete uygun olan ulusal gelenekleri uygulamalıdır. Sanatçı toplumun bugünkü başarısını kavramak ve Komünizmin kaçınılmaz zaferini sağlamak zorundadır. Sosyalist Gerçekçilik, sanatın ayrılmaz bir şekilde hükümete bağlanmasını sağlar ve şu anki politikayı aydınlatır. Aynı şekilde siyaset de sanatta gerçekçi temsilleri belirler. Sosyalist Gerçekçilik'te üçüncü zaman ilkesi ise, geçmişin, şimdinin ve geleceğin toplumlarını birleştirmede sanatın ve politik gücün karşılıklı̆ını doğrular. Sosyalist Gerçekçilik, öğretilerinin gelecekte gerçekleşmesini sağlamak için döngüsel bir şimdiki zaman yaratır. Sosyalist Gerçekçilik’te devlet kültürü talep eder. Dahası, kültür konularının özümsenmesinde, tarzın dikte edilmesinde ve tamamen mutlak otoriteye entegre edilmesinde, devlet sanat haline gelmiştir (Paletz, 2001, s. 570). Sosyalist Gerçekçilik'in Sovyet sinemasına dayatılması ve ideolojinin sinemaya çok fazla dâhil olması, sistemin korunmasına yönelik bir önlem olarak da düşünülebilir. Tehdit olan toplumlarda ideoloji bir savunma mekanizmasıdır.

İkinci Dünya Savaşı döneminde Sovyet sineması Sovyetler Birliği’ne bağlı ülkelerde daha fazla kontrolcü ve propagandacı bir tavır izler. Hitler'in 1941'de Sovyetler Birliği'ne saldırmasıyla birlikte Sovyet sinema endüstrisi hızlı bir şekilde harekete geçirilir ve eldeki kaynakların çoğu belgesel filmlere ayrılır. Ünlü yönetmenler haber filmlerini kurgulamaları için ikna edilir ve stüdyolar çekilmekte olan filmleri savaş sahneleri ekleyerek değiştirmeye başlar. Uzun metraj filmlerin hem maliyetli olması hem de çekim 
sürecinin uzun olması stüdyoları kısa film yapmaya yönlendirir. 30’lu yıllarda yoğun olarak çektirilen, sabotajcılar ve vatan hainleri gibi iç düşmanları konu alan filmler, 40'larla birlikte yerini dış düşmana, yabanclara ve ajanlara bırakır. Cephedeki kahramanlıklar öne çıarılırken cephe gerisinden de genellikle kadınları konu alan, sadakat, dayanıklık, özveri gibi erdemleri ön plana çıkaran filmler yapılır. Özellikle Nazilere karşı yapılan filmlerde Sovyetler Birliği’ne dâhil olan ülkelerin ortak bir düşmana karşı savaştığının ve birlik olunması gerektiğinin altı çizilir. Peter Kenez’e göre savaş dönemi, yakın geçmiş ve gelecek dönemler dikkate alındığında bir "özgürlükler vahası" gibi değerlendirilebilir. Rejim, bu dönemde sanatsal çalışmalara belli ölçüde izin verir; fakat savaş sonrasında eski baskıcı dönem yeniden başlar. Stalin, savaş sırasında zayıflayan ideolojik kontrolü yeniden kurma amaciyla bazı adımlar atar; fakat bu talepler ve yapılan müdahaleler baskıyı arttırdığı ve üretimi zorlaştırdığı için sinema endüstrisini durma noktasına getirir. Bürokratik müdahaleler, tek boyutlu politik mesajlar, görüntünün ve yönetmenin arka plana atılarak bireysel üslubun bitirildiğgi "demir senaryo" uygulaması sinemaya zarar verir. Stüdyoların boş kaldığı, genç yönetmenlerin kendilerini geliştirme olanağı bulamadığı, yılda ondan az filmin üretildiği bu dönemde sinemalarda savaş zamanından kalan filmler gösterilir. Stalin'in 1953’te ölümüne kadar bu şekilde devam eden "kısırlık", siyasal düzendeki değişikliklerin ardından yerini canlılığa bırakır. Geçmişte çalışmalar üreten yönetmenler tekrar sahaya döner ve yeni yönetmenlerin ortaya çıkışı da hızlanır. Sovyet sineması 1920’lerdeki prestijini tekrar kazanamasa da filmler tekrar izlemeye değer olur ve kültürel yaşama olumlu katk1lar yapar (1996, s. 389-398).

\section{Sovyet Animasyonları Tarihine Genel Bir Bakış}

Sovyet animasyonu, devletin siyasi otoritesiyle animasyonun kendine özgü dünyası ve olanaklanı arasında sıkışmış bir sinemadır. İlk yıllardan itibaren hemen her şeyin kullanılarak oluşturulduğu stop motion animasyonlardan 1930'larda Disneyvari şekilde geleneksel animasyona geçen ve sonrasinda cam boyamalara kadar çeşitlenen bu animasyon sineması, tarihi boyunca oldukça özgün ve deneysel çalışmalar üretir. Sanatsal kaygılardan ziyade işlevsel kaygıları ön plana alması ve iç dinamikleri hedefleyen bir yapıda olması, kendi ülkesiyle ve toplumuyla sınırlı kalmasının öncelikli nedenidir. Toplumun hafısasından ve kendi görsel kültüründen de beslenen bu animasyonların alegorilere ve metaforlara olan yatkınlıkları zaman zaman sert ve didaktik unsurların kullanıldığı propagandif silahlara dönüştürülmelerine de neden olmuştur. Böylece salt eğlendirme unsurundan ziyade hükümetin ideolojik, siyasi, toplumsal ve psikolojik amaçlarına da hizmet ettiği görülür.

Sovyetler Birliği, 1920'lerde başlayan propaganda döneminden önce de dünyada öncü olmuş pek çok önemli eser üretmiştir. Sovyetler Birliği’nin ilk animatörü, animasyonu dans tekniklerini öğretmek için bir araç olarak kullanan Alexander Shiryaev'dir. 1906 ve 1909 yılları arasında bu dans filmlerini ürettiği tahmin edilen Shiryaev, ilk kukla animasyonu örneklerini yapmıştır ve 1995 yllında filmler keşfedilene kadar da filmlerden kimsenin haberi yoktur (Bocharov, 2004). Sovyetler'in animasyondaki bir diğer önemli ismi ise stop-motion türünün bir tür olarak gelişmesine katkı sunan Ladislas Starevich ${ }^{3}$ tir. Starevich'in hamam böceklerini kullanarak oluşturduğu stop motion film Güzel Lenkanida (Prekrasnaya Lyukanida, ili Voyna usachey $s$ rogachami) (1912) bir kara mizah örneğidir. ${ }^{4}$ Bu tarz filmleriyle korku unsurlarını duygusal bir şekilde ele alan Starevich, tuhaf ve ilgi çekici hikâyeleriyle pek çok çalışma ortaya koyar ve başta Tim Burton ve Quay Kardeşler olmak üzere pek çok yönetmeni etkiler (Sawicki, 2010, s. 73). Starevich, 1912'de 4, 1913'te 1 ve 1914'te 2 film üretmiştir. Bu tarihlerden sonraki ilk çalşsmalar 1923 tarihindedir. Veritabanlannda Alexander Shiryaev'in adı kullanılmamışır (Animator.ru).

Bolşevik Devrimi'nden sonra ise sinema gibi animasyon da devlet mekanizmasının etkisine girer ve devlet eliyle yapılan -ve bazıları da propaganda amaçlı olan- filmler üretilmeye başlar. Dziga Vertov'un propaganda unsurlarıyla bezenen Sovyet Oyuncaklar (Sovetskiye igrushki) (1924) filmi ilk Sovyet animasyonlarından biri olurken, 1927 yılında yapilan Afrikalı Senka (Sen'ka-afrikanets) da çocuklara yönelik yapılan ilk animasyondur. Mikhail Tsekhanovsky'nin yaptı̆̆1 -bir postanın taşınma hikâyesinin anlatıldığ1Posta (Pocbta) (1929) filmi de döneminde oldukça popüler olmuş, Sovyetler Birliği’nin dişında da gösterilmiş ve avangard üslubuyla farklılaşmış bir filmdir (Bendazzi, 1995, s. 47). 1935 yllına gelindiğinde ise gerçek

\footnotetext{
3 Gerçek adı Wladyslaw Starewicz'dir. Devrim sonrasında 1920'de Rusya'dan ayrılarak Fransa'ya yerleşir ve adını Ladislas Starewitch olarak değiştirir. Fransa'da ürettiği 24 filmi bu isimle yapar. İngilizce kaynaklarda adı Ladislas Starevich olarak kullanılır. Film çalışmalarına yerel Etnografya Müzesi’nde belgeseller hazırlayarak başlar. İlk yaptığı çalışma, karanlıkta kayda alınamayan yerel bir böcek türünün gece çiftleşme ritüelinin yeniden canlandırılmasıdır. Eğlence amaçlı ilk ürettiği filmde ise hayatı boyunca kullanacağı kukla yapma tekniğini geliştirir (Moritz, 1997, s. 76).

${ }^{4}$ Filmin İngilizce gösteriminin ardından Londra gazeteleri böceklerin gerçek olduğunu ve adı belirtilmeyen bir Rus bilimadamı tarafından eğitildiklerini yazmıştır (Bendazzi, 1995, s. 36).
} 
görüntüyle stop motion tekniğini birleştiren ve yaklaşık 3000 farklı kuklanın kullanıldı̆̆1 Sovyetler Birliği'nin ilk uzun metraj animasyonu olan Yeni Gulliver (Novyy Gulliver) filmi görücüye çıkmıştır. Film, Jonathan Swift'in Gulliver'in Gezileri kitabının komünist bakış açısıyla yeniden uyarlamasıdır.

1920’lerin sonuna doğru animasyon üretimi artsa da sosyalist gerçekçi akımın devreye sokulmasıyla birlikte yenilikçi çalışmalar azalır ve daha "gerçekçi" ama daha az "sanatsal" çalışmaların dönemi başlar. Önceki on yllda avangardın ve fütürizmin etkisiyle çalışan animatörler, klasik metinlerin adapte edildiği, çocuklara yönelik çalısmaların yapıldığı ve geleneğin kullanıldı̆̆1 "ulusal kültürün hizmetine" sokulur. Animasyonun çocuklara yönelik bir sisteme bağlanması 1936 y1lında Moskova'da kurulan Soyuzdetmultfilm'in adından da anlaşıır. "Det" çocuk anlamındadır ve "mult" da multiplikatsija'dan yani animasyon kelimesinden gelir (Bendazzi, 1995, s. 101). Bir yıl sonra adından "det"i çıkarıp Soyuzmultfilm halini alan bu kurumun kuruluş süreci iki ylllık bir çalışma sonucunda gerçekleşir. ${ }^{5}$ Stüdyo, -Walt Disney'in montaj hattı sistemini kopyalayarak- animasyon üretimini merkezileştirmeye ve daha standart bir üretim formuna döndürmeye başlar. Bu yöntem, opak bir arkaplana ve saydam selüloit tabakalar üzerine yapılan, birbirini izleyen ardışı haraket çizimlerinin kare kare çekilmesidir. Bu prensip, animasyon yapımını hem hızlandırır hem de maliyetleri düşürür (Romashova, 2011, s. 119). Soyuzmultfilm'in kuruluş adımının atılmasında 1933'te bazı Disney animasyon örneklerinin gösterildiği bir festivalle, 1935'te ilk kez düzenlenen Uluslararası Moskova Film Festivali'nin büyük etkisi vardır. Moskova Film Festivali'nde Üc Kücük Domuz. (Three Little Pigs) (1933), Tubaf Penguenler (Peculiar Penguins) (1934) ve Grup Konseri (The Band Concert) (1935) filmleri gösterilir. Ayrıca 1930'larda aralarında Grigorii Aleksandrov ve Sergei Eisenstein'in de olduğu bir grup film yapımcısı ABD'yi ziyaret eder ve burada Disney'in çalışmalarıyla ve film üretim yöntemiyle tanışır. Eisenstein, film üretim tekniğindeki gelişmişliğin yanında özellikle Disney filmlerinde insanlarla hayvanların ilişkilendirilmesinden ve her iki kimliğin özelliklerinin birleştirilmesinden etkilenir. Böylece sosyal yorumların hayvan dünyasına aktarılması ve -Sovyet, Stalinist gibi- sözle anlatılması zor olan bazı gerçekliklerin sunulması mümkündür (Balina ve Beumers, 2015, s. 126-127). ${ }^{6}$ Fyodor Khitruk, Walt Disney'in çizgi filmlerini Moskova Film Festivali’nde ilk kez gördüğü zamanki izlenimlerini şöyle ifade eder:

Sacma Senfoni (Silly Symphony) serisinden olan Disney filmi, bildiğimiz sınıllara uymuyordu. Bir yönetmenlik işiydi. Müziğin, fikirlerin, karakterlerin ve plastiğin bir birleşimiydi. İnanılmazdı. Ruhuma gömüldü. Kendim yapmayı hayal bile edemezdim. Benim için bu filmler sanattan ziyade bir sihirdi, büyücülüktü. Hareketteki, karakterdeki, oyundaki bir şey benim için kurmaca filmlerden daha ikna ediciydi. (1997, s. 24)

Walt Disney animasyonlarıyla yaşadığı benzer bir tecrübeyi Sergei Alimov da şu şekilde aktarır:

Pamuk Prenses ve Yedi Cüceler (Snow White and the Seven Dwarfs) izlediğim ilk animasyondu. Tabii ki animasyonun mesleğim olacağını hiç hayal etmiyordum. 'Pamuk Prenses' beni vurmuştu. Belki de sonradan beni sadece tek bir animasyon etkilemiştir: George Dunning'in Beatles'in Sar Denizalttsı (The Beatles' Yellow Submarine). Ama o çok sonraydi. Sanat okulunun son sinifindan hemen önce, animasyon sanatı okumak için VGIK’’a gitmeye karar vermiştim. (1997, s. 7)

\footnotetext{
${ }^{5}$ Pek çok kaynakta stüdyoyu Mezhrabpomfilm, Mosfilm ve Smirnov Studio’daki animatörlerin bir kereleliğine bir araya gelerek oluşturduğu yazar, fakat Rus animasyon tarihçisi Georgy Borodin işin bu kadar kolay olmadığını belirterek stüdyonun kuruluş aşamasını dört aşamalı olarak detaylandırmıştır. Borodin, 2006 yılında yazdığı makalede Soyuzmultfilm'in tarihinde değinilmeyen pek çok olay olduğundan bahseder. Bunlardan bazıları: stüdyonun 1941 yllının sonunda bir süre Moskova ve Semerkand olarak ikiye ayrılması, yeni animasyon sanatçılarının yetişrildiği kurslar, tematik planların yapılarındaki değişimler, üretim organizasyon sistemi, teknolojik evrimin aşamaları, senaryo departmanı ve diğer stüdyo bölümlerinin oluşumu ve faaliyetleri, stüdyo içi etkinlikler, 80 ’lerin sonundaki reform vb. Borodin, makaleyi yazdığı tarihte stüdyonun yaptığı reklamların, oyunların, videoların ve filmlerin kapsamlı bir listesinin bile olmadı̆̆ından, tamamlanmayan çalışmaların da göz ardı edildiğinden bahseder. Ayrıca Borodin, Soyuzmultfilm'in 1999 yllında gizli bir şekilde -Rus yasalarını ihlal etmesine rağmen- özelleştirildiğini ve sonrasında aynı ismi kullanan pek çok yapıya bölündüğunü söyler. Bunlardan bazıları film üretimine, bazıları daha önce üretilen filmlerin yayın haklarına ve kârlarına, bazıları da kültürel ve eğitici çalışmalar yapmaya odaklanmıştır (2006).

${ }^{6}$ Bu festivalde Disney filmlerine ek olarak Lloyd Corrigan'ın Pioneer Pictures Corporation için yaptığı kısa bir müzikal olan $L a$ Cucaracha (1934) da gösterilir. Technicolor Corporation tarafindan en son renk tekniği uygulanarak oluşturulan film, Sovyetler’in 1920 ’lerin ortalarında başlayan film ve fotoğraf üzerindeki renk çalışmalarını da büyük ölçüde etkiler. Pravda gazetesi başta olmak üzere basının ve festival izleyicisinin geri dönüşleri sonucu bu film de dağıtım için satın alınır. Böylece ABD ile eşit şartlarda rekabet edebilmek, Sovyet film endüstrisinin "göreceli” teknolojik geriliğinin üstesinden gelmek ve Sovyetler Birliği’nin planlanan ekonomisinin dinamik potansiyelini göstermek adına renkli film çalışmaları hızlandırılır (Cavendish, 2019, s. 571).

${ }^{7}$ Rusya Federasyonu Devlet Gerasimov Sinematografi Enstitüsü’nün kısaltmasıdır.
} 
Disney'in kullandığ1 sel animasyon tekniği animasyona oldukça estetik ve akıcı bir hareket verir. Disney'in hareket için oluşturduğu prensipler, etkileyici yüz ifadeleri, abartıll jestler ve diğer basit teknikler önce V. F. Smirnov'un önderliğindeki deneysel stüdyoda, sonra da Soyuzmultfilm'de uygulanmaya başlar. Büyük Vatanseverlik Savaşı'nı takip eden on beş yılda Sovyet animasyonu pratikte "Disney tarzl" ${ }^{n}$ k korur ve orijinal bir tarz arayışına ya da avangard denemelere girişmez. Disney'le olan teknolojik ilişkinin Sovyet animatörleri üzerinde -sonradan fark edileceği üzere- bazı negatif sonuçları da olur. 1953’ten sonra pek çok yetenekli genç yönetmen ortaya çıkmasına ve Sovyet uzun metraj filmler yapılmasına rağmen "Thaw" dönemi Sovyet animasyonundaki beklenen devrimi getirmez. 1960'larla birlikte temel olarak folklorik ve etnik motiflerin dâhil edildiği küçük stilistik ve tematik yenilikler gerçekleşir. Sosyalist bloktaki Yugoslav, Çekoslovak ve Leh animatörler cesur kısa filmler üretirken, Sovyet animatörler geleneksel çizimleri ve didaktik içerikleri kullandıkları, dramatik anlatı yapısını inşa ettikleri anlayışlarını korumaya devam eder (Leving, 2008, s. 317).

Sovyetler Birliği’nde sosyalist gerçekçilik etkisiyle rotoskop tekniği çok fazla kullanılır. Sovyetlerin kullanılan projeksiyon markası nedeniyle- "éclair" olarak isimlendirdiği bu teknik 1920'lerden itibaren kullanılsa da 1950'lerde zirve noktasına ulaşır ve üretilen filmlerde çok gerçekçi arka planlar ve karakterler elde edilir. Özellikle 1950-1955 döneminde éclair kullanılmayan neredeyse hiçbir film yoktur ve hayvan karakterlerin çoğunda bile aynı teknik kullanılır. Bu yöntemle ilgili o dönem bazı yönetmenlerin ve sanatçıların eleştirileri vardır. Tekniğin aşırı mekanik kullanılması, aktörlerle tekrar yapmak için zaman olmaması, aktörlerle hızlı çalışmanın getirdiği özensizlik ve hiçbir aktörün çizilen bir karakteri ifade edemeyeceği düşüncesi bunlardan bazılarıdır (Ivanov-Vano, 2006).

Stalin'in ölümü ve Thaw dönemiyle birlikte animasyonlar yavaş yavaş eski avangard ve sanatsal formuna dönmeye başlar ve rafa kaldırılan kukla animasyonu da tekrar üretim bandına girer. 1960'larla beraber sosyalist gerçekçiliği geride bırakan Sovyet animasyonu, -ABD'de de olduğu gibi- televizyonun etkisiyle daha hızlı bir üretim yöntemine evrilir ve daha limitli bir animasyon tarzına döner. Böylece sadece karakterlerin hareketleri kısıtlanmaz, ayrıca sade formlara ve renklere de ağırlık verilir. Öncelikler tasarıma, renge, çizgiye ve kompozisyona geçmiştir (Amidi, 2006, s. 18 Akt: Pikkov, 2016, s. 24). Böylece limitli animasyonun işlevselliği Sovyet animasyonunun kabuk değiştirmesine ve artık Disney tarzından sıyrılmasına katkı sağlayarak, bir anlamda köklerine -yani devrim sonrasındaki animasyonlara ve propaganda posterlerine- dönmesinin bir sinyali olarak düşünülebilir. Böylece animasyon endüstrisinin kaynak ihtiyacı azaltılmış ve üretim hacmi artmıstır (Pikkov, 2016, s. 24).

1960'ların sonuna doğru çocuk ve genç izleyicilerin eğitimi ile olan bağından kurtulmaya, kendi tarzını aramaya ve avangard denemeler yapmaya başlayan animasyon alanı pek çok yetenekli sanatçının animasyona yönelmesine katkı sağlar. Bunda -film yapımının aksine- animasyon üzerine görsel ya da işitsel özel bir ideolojik kontrolün olmaması da etkilidir. Ayrıca 1960’larda Soyuzmultfilm tekel olmaktan çıar ve bölgesel yeni stüdyolar açlır. Böylece bu stüdyolar kendi çocukluk imajlarını oluşturma firsatına kavuşur ve merkezle olan ilişkileri sona erdikçe, altyapı oluşturmaya başladıkça, profesyonel topluluklar haline geldikçe ve üretim özellikleri geliştikçe animasyonun bir sosyal etkileşim, süregelen bir mücadele ve dönüşüm alanı olmasını sağlar. Romashova, 1960'larda animasyonun yaygınlaşmasının önemli sebebi olarak televizyonu gösterir. 1960-1980 arasında televizyon Sovyet halkının refahının bir sembolü haline gelir. Bundan önce animasyonlar için tek mecra sinemalar olduğu için, animasyonların diğer filmlerle rekabet etme şansı yoktur. Televizyonla birlikte animasyonlar "evcilleşir" ve ailelerin evde kontrol edebildiği, çocukların tek başlarına izleyebildiği bir forma dönüşür (2011, s. 115-117).

Bendazzi, dönemin politik ortamının ve metinle kısıtlanan -nispeten daha az sık1- sansür mekanizmasının sadece Sovyetler Birliği’nde değil bütün Doğu Avrupa ülkelerinde bir auteur animasyon akımı oluşturduğundan ve devletin burada "patron" olduğundan bahseder. Bunda da iki blok arasında kültürel ve sportif rekabeti gerekçe olarak gösterir:
Bir gerekse vard. Kültür ve spor iki blok arasinda diyalog ve mücadele alan baline gelmisti. Bir Olimpiyat madalyast ya da bir festival büyük ödülï sabte bir savaşstaki sabte bir zaferdi. Doğu Avrupa'da bir festival ödülï, stüdyo direktörü için -bakanllktan finansman desteğgi istedig̈inde- elinde bir koz olarak görülürdü. Ama gene de tam bir yaratıc özgürlük asla verilmedi. Ideolojik teblikeleri nedeniyle baž filmler yaymlanmad. Bunlar için-alegorik taraflarm belirtmek, amaģh- "Ezop yaklaşım”" ifadesi kullamild. (2015, s. 236)

\footnotetext{
8 Ivan Ivanov-Vano, animasyon tarihini ve tekniklerini anlattığı kitabında Disney'den etkilenme meselesinden bahsetmez ve Sovyet animatörlerin Disney'in fikirsiz, biçimci, adi ve ucuz yapısına karşı olduklarını söyler. Kitabın başka bir yerinde de "burjuva animasyonu" olarak nitelediği Disney’i saçma, basit ve ucuz numaralı filmler yapmakla itham eder (1950, s. 17, 21).
} 
Bu sembolik ve eleștirel kodların yer aldığı animasyon akımı Almanya'da Birinci Dünya Savaşı'ndan sonra etkisini arttıran ekspresyonist filmlere benzetilebilir ve bu filmlerin en bilinen örneği de Andrei Khrzhanovsky'nin Cam Mįıka (Steklyannaya garmonika) (1968) filmidir. Bir çeşit toplum eleştirisi olan film içerdiği eleştirel sembolik anlatım nedeniyle -Soyuzmultfilm çatısı altında üretilmesine rağmen- sansür kurulunca kusurlu bulunur ve Sovyetler Birliği'nde resmi olarak yasaklanan ilk animasyon film olur (Cavalier, 2011, s. 196).

1960’larda yükselen avangart üslupla birlikte çağdaş ve özgün animasyonların üretilmesi, yapılan çalışmaların uluslararası arenada da fark edilmesini sağlar. Dönemin öncü isimlerinden Fyodor Khitruk, uluslararası arenada da oldukça önemli başarılar kazanır ve kapitalizm eleştirisi yapan Ada (Ostrov) (1973) filmiyle Cannes Film Festivali'nden Altın Palmiye alır. Hem ABD'den hem de Avrupa'dan ödüller alan Film Film Film (Fil'm, fil'm, fil'm) (1968) filminde ise film yapmak üzerine -Sovyet bürokrasisini eleştirdiğiesprili bir hiciv ortaya koyar. Khitruk, sosyal sorunları ele alan, güncel kalmayı seven, zeki ve "dertli" bir zanaatkârdır. Bir konuşmasında "sosyal sorunlarla ilgilenmeyen bir sanat olduğuna inanmıyorum ve insanla ilgilenen her şey kendi başına bir sosyal sorundur" der. Gene de devrimci bir yönetmen değildir ve gelenekten beslenmeyi ve çocuklara yönelik işler üretmeyi sürdürür (Bendazzi, 2015, s. 370). Yaptı̆ğ uyarlamalardan en bilineni ve ilgi çekeni A. A. Milne'nin aynı adlı eserinden uyarlanan Winnie the Poob (Vinni-Pukh) (1969)'tur. Amerikan uyarlamasına göre biraz farklılaşan film, karakter tasarımlarında da orijinal eserdeki illüstrasyonlara bağlı kalmaz. ${ }^{9} \mathrm{Bu}$ dönemde Sovyet animasyonunun uluslararası popülaritesini ve bilinirliğini de arttıran başka animasyonlar da ortaya çıkar. 1969 yllında Roman Kachanov tarafindan yapilan Timsah Gena (Krokodil Gena) filmi Sovyet animasyon tarihinin önemli filmlerinden biri olur. Filmin karakterlerinden olan Cheburashka, hem kendi ülkesinde hem de ülke dışında çok sevilen bir karaktere dönüşerek Amerika'da Mickey Mouse'un oluşturduğuna benzer bir etkiyi Sovyetler Birliği'nde oluşturur. Cheburashka, 2004-2010 yılları arasında Rusya Olimpik takımının da resmi maskotu olur ve böylece uluslararası arenada da boy göstermeye ve tanınmaya başlar (Palumbo, 2018). Sadece Bekle! (Nu, pogodi!) (1969-2007) ise Tom ve Jerry'nin Sovyetler Birliği’ndeki alternatifi olarak gösterilebilir. Bir kurtla bir tavşanı konu alan animasyon düzenli bir üretim gösteremese de uzun yıllar devam eder ve özellikle Doğu bloğu ülkelerinde ve Sovyetler Birliği'nde çok popüler olur. Benzer -hatta daha büyük- bir popülerlik Sovyetler Birliği sonrası gelişen Rus animasyonununda da görülür. 2009 yllında ortaya çıkan ve küçük bir kızla bir ayının hikâyesini anlatan Masha ve Ayz (Másha i Medvéd') animasyonu özellikle 1990'dan sonra kriz dönemine giren Rus animasyonunu canlandıran ve bütün dünyada ilgiyle izlenen bir seri olur.

Uluslararası arenada isim yapan bir diğer önemli Rus yönetmen de Yuri Norstein'dir. Norstein, Soyuzmultfilm'e yirmi yaşında bir ressam ve sanat yönetmeni olarak girer ve pek çok projede yer aldıktan sonra yönetmenlik yapmaya başlar. Norstein filmlerini sembolik anlatımla yoğurarak minimalist bir üslupla ele alır ve bu açıdan Sovyet animasyon tarihinde farklı bir yer elde eder. Rüya ve gerçeklik arasındaki ilişkiyi şiirsel bir üslupla ele aldığ1 Sisteki Kirpi (Yozhik v tumane) (1975) filmiyle, anlatım yapısı olarak Andrei Tarkovsky'nin Ayna (Zerkalo) (1975) filmine benzeyen ve adını da Nazım Hikmet'in aynı adlı şiirinden alan Masallarn Masalı (Skąka skąok) (1979) filmi en bilinen iki çalışmasıdır. Norstein yaptığı çalışmalarla başta Hayao Miyazaki olmak üzere pek çok sanatçıyı etkilemiştir. 2004 y1lında Japon hükümetinden Japonya'ya ve Japon toplumuna hizmet edenlere verilen bir ödül alır. 2003 yllinda Sisteki Kirpi filmi, 140 film eleştirmeninin ve animatörünün katıldığı bir oylamada tüm zamanların en iyi animasyonu seçilir. Aynı oylamanın ikinci sırasında da Norstein'ın bir diğer filmi Masallarm Masalı yer alır (BBC, 2004). Bendazzi, Masallarn Masal filmini insan ruhunun ağıtsal bir okuması, duygusal bir araştırma ve yeniden keşif, zamanın ve jenerasyonun manevi kökleri olarak tanımlar. Filmle ilgili şunları şöyler:

\section{Norstein'in basyapıt (ve Soryet animasyonunun da basyapitt) olan 'Masallarm Masali' zibinsel çağgrş̧ımlar üzerine bir filmdir. 27 dakikallk görüntü akışı biricik bir hayal ürünüdür: çocukluk ve savas amlar, Puskin'in çizimleri, Picasso'ya referanslar, sebrin eteklerinde bir tango, Bach'in Well-Tempered Clavichord'u, Mozart'in Concert No. 5 F Minör'ü... Ünlü bir Rus ninnisinin söylediği gibi: uyu, uyu ve gri kurt yavrusu seni ormana götürecek... (2015, s. 372-373)}

1980'lerle birlikte Mihail Gorbaçov'un önderliğinde siyaset ve ekonomi alanında getirilen yenilikler animasyon alanındaki kısıtlamaları da kaldırır ve o döneme kadar tabu olan pek çok konunun ele

\footnotetext{
9 “Winnie the Pooh” kitabının haklarını A. A. Milne'den 1929 yılında Stephen Slezinger almıştır, fakat bu haklarla ABD'de birkaç popüler oyun yapmak dışında bir çalışma yapılmaz. Haklar 1961 yılında Disney Stüdyoları tarafindan tekrardan alınır ve 1966 ile 1968 yıllarında iki film üretilir. Khitruk, kendi versiyonunu yaptığında diğer iki filmden haberdar değildir (Leving, 2008, s. 316).
} 
alınabilmesinin önünü açar. Devlet eliyle yapılan bu "sosyal eleştiri izni” Sovyetler Birliği’nin dağılması nedeniyle uzun soluklu olmaz. Böylece geçmiş dönemde baskın bir şekilde hissedilen politik hegemonya ve daha sistematik bir şekilde ilerleyen animasyon üretimi 1980'lerin sonunda zayıflamıştır. Faraday, bu dönemde gerçekleşen "siyasi demokratikleşme"nin ve piyasa değişiminin yasallaştırılmasının ülkeye bilgi ve ürün akışını ciddi biçimde arttırdığını söyler (Faraday, 2000, s. 181 Akt: Fadina, 2016, s. 92). Nitekim "khozraschet" ile birlikte tüm üretim birimleri kendi kendini finans etme sistemine geçer ve böylece Amerikan filmlerinin toplu ithalatı gerçekleşir. Sovyet izleyicilerinin "Amerikanlaşmasını" ve "Batılılaşmasını" arttıran bu süreç, "Rus" etiketiyle çıkan her şeyin olumsuz olarak algılanmasını da beraberinde getirir. Böylece 1970’lerde yerel geleneğe olan ilgi de 1980'lerle birlikte ortadan kalkmıştır (Fadina, 2016, s. 93).

Sovyet animasyon sinemasından bahsederken propaganda amaçlı yapılan animasyonlara da değinmek gerekir. Animasyon, propagandaya uygun bir yapıdır, çünkü gerçek olmayan bir dünya kurma yeteneğiyle, önemli bir görsel özgürlük sağlamasıyla ve sanatçıya bazı kültürel değerleri keskinleştirme bazılarını da gizleyebilme olanağı vermesiyle öne çıkar. Abartma özelliği, "sizin" ve "başkalarının" arasında açık bir sembolik sınır çizme imkânı verir ve bu nedenle siyasi propagandada yaygin olarak kullanılır. Hikâye anlatma ve müzik gibi olanakları sayesinde karikatüre göre -izleyici nezdinde- daha ikna edicidir. Animasyonlar propaganda potansiyeli sayesinde özellikle İkinci Dünya Savaşı sırasında ve ardından gelen Soğuk Savaş’ta önemli bir silah olarak kullanılır.

ABD'nin Sovyetler'e karşı eleștirel tavrı özellikle 1949'daki -ABD'yi “ana düşman” olarak hedef alan"Yakın Gelecekte Amerikan Karşıı Propagandayı Güçlendirme Aksiyon Planı" sonrasında artar. 1 Nisan 1949'da NATO'nun kurulmasindan sonra yazar Konstantin Simonov, Komünist Parti Merkez Komitesi’ne içinde Anti-Amerikan propagandasına yönelik önlemler içeren bir draft gönderir. Bu draftın Agitprop tarafindan onaylanması sonucunda bu belge yayınlanır. Belgedeki maddeler genel olarak: a) Gazetelerde Amerikan emperyalizmine, Amerikanın "sözde" refahına, burjuva kültürünün ve ahlakının sahtekârlıklarına yönelik sistematik yayınlar yapılması, b) Amerikan karşııtı broşürler ve makaleler yayınlanması, c) Radyolarda Anti-Amerikan propagandasını güçlendirecek konuşmalar yapılması, ç) Amerikan emperyalizminin dünya çapındaki planları üzerine halka verilen derslerin arttırılması, d) Sovyet yazarların eser üretmesi için teşvik edilmesi, e) Anti-Amerikan hiciv posterleri yayınlanması, f) Amerikan karşııı oyunların sayısının arttırılması ve en iyi yönetmenlerin ve oyuncuların kullanılması, g) Amerikan karşıtı konularda film üretilmesi ve mevcut filmlerin dolaşımının arttırılması üzerinedir (Merkez Komite, 1949).

Sovyet ideolojisinin uygulanı̧̧ı iki yönlüdür: Sovyet insanının yüksek ahlaklı karakterini göstermek ve burjuva toplumlarının bozulmuş ahlaki durumunu teşhir etmek. Sovyetler Birliği sinemayı -ve animasyonubu çerçevede başarıyla kullanmıştır. Özellikle Soğuk Savaş döneminde -hem çocuklara hem de yetişkinlere yönelik- üretilen çalışmalarda ABD'nin ideolojik bir rakip olarak sunulduğu ve çeşitli açılardan kötü gösterildiği görülür. Sovyet ideolojisi, "kötü Amerikalılar"'n karşısına "iyi”" olarak komünistleri, işçi sınıfını, barış savaşçılarını ve Afro-Amerikalıları ${ }^{10}$ çıkarır ve "sıradan" Amerikalılar sempatik bir şekilde tasvir edilir (Riabov, 2018, s. 90-91, 98).

Sovyetler'de uygulanan propaganda animasyonlarının geneli Batıll imgesini -özellikle ABD'yi- ve kapitalizmi kötülemeye yöneliktir. Bu filmlerde kapitalist, burjuva, toprak sahibi, rahip, casus ve karş1 devrimciler karikatürize edilerek "düşman" olarak verilir ve kötü gösterilir. Kurulan iyi-kötü çatışması da aslında birey toplum arasındaki karşıtlık üzerine kurulur (Taylor, 1998, s. 52). Çağrı İnceoğlu, yaptığ1 çalışmada Sovyet animasyonlarında Batılı imgesini temel olarak üçe ayırır: a) kapitalist, emperyalist ve barbar, b) yozlaşmış ve kültürsüz, c) mazlum ve masum. Soğuk savaş dönemi öncesinde Batılı figürü çirkin ve saldırgan bir kapitalist olarak resmedilir. Soğuk savaş dönemiyle birlikte ise daha çok yaşam tarzı eleştirisine yönelik bir anlatım vardır. Daha hayvansı ve canavarsı bir şekilde çizilen karakterler daha insansı bir özellik kazanmaya başlar. Kapitalizmi eleştiren bu filmler bir taraftan da karşıt ideolojilerin özellikle ABD'nin- zayıf noktalarına yüklenir. Bunların en önemlisi ırkçılık sorunudur ve Batılı 1rkçı tip animasyonlarda sıkça kullanılır. Bunun yanında kent olgusu ve metropol yaşamı, trafik, kalabalık, alışveriş ve lüks tüketim, eğlenceye düşkün hayat tarzı vb. şeyler gene Batı ile özdeşleştirilerek olumsuzlanan detaylar olarak göze çarpar. Amerikan rüyası da sosyalist ideolojiyle bağdaşmayan bir unsur olarak kötü

\footnotetext{
10 Genç siyahi Amerikalılar'ın Sovyet çocuklarıyla arkadaş oldukları pek çok yapım vardır. Buna örnek olarak 1949 yapımı Mashenkin Konseri (Mashen'kin kontsert) ve 1953 yapım1 Ay'a Yolculuk. (Polet na lunu) verilebilir.
} 
gösterilir ve filmlerde özellikle özel mülkiyete sahip olma isteği olumsuz bir durum olarak kullanılır (2013, s. 34-37).

Sovyetlerin propagandif unsurları sadece propaganda amacıyla üretilen kısa animasyonlarda değil başka çalışmalarda da yer alır. 1935 yılında Aleksandr Ptushko tarafindan yapılan Yeni Gulliver (Noryy Gulliver) filmi, Sovyetler'in öncü uzun metraj filmlerden biridir ve ayrıca bir stop-motion animasyondur. Ptushko'nun filmi Jonathan Swift'in çok bilinen alegori kitabı Gulliver'in Gezilerinden yapılan bir komünizm uyarlamasıdır. Film, monarşiye, kapitalizme ve modern topluma karşı doğrudan bir tavır alarak bunu pek çok sahneye yayar. Gerçek görüntüyle animasyonu harmanlayan film 3000'den fazla figür kullanır ve yapım mantığı açısından- günümüz stop-motion filmlerinde de kullanılan bir yöntemle yapilır. Bazı karakterler için kullanılan ve her hareket için farklı üretilen değiştirilebilir kafalar filmdeki karakter sayısı dikkate alındığında oldukça büyük bir ön çalışma gerektirmiştir. Isşçiler bilinçli olarak birbirlerine benzer ve daha insan görünümlü- olarak ifade edilir, fakat asiller ve kralın adamları daha karakteristik ve daha şekilsiz, ince bacaklı ve uzuvları zaman zaman değissen şekilde oluşturulmuştur. İşçilerin belli bir kimliği ve karakteri yoktur ama kralın adamlarının ve asillerin -olumsuzlansa bile- belli bir karakteri ve kimliği mevcuttur. İdeolojik amaçlarını gizlemeyen film, çoğu sahnede Lilliput ülkesinin kapitalizmin, eşitsizliğin ve istismarın hüküm sürdüğ̈ bir yer olduğunu dile getirir. Asiller lüks ortamda ve şartlarda yaşarken işçiler mağaralarda yaşar ve üretim yapar. Asillerin taktı̆̆ eski peruklar da bir çeşit Batılı imgesi oluşturur. Sovyet propaganda animasyonlarının çoğunda görülen "şişman, çirkin ve obur Batıllı", "Batıll'ya hizmet eden -ve Katolik ya da Ortodoks olması fark etmeyen- din adamı" ile "bunlara karşı savaş veren işçi-çiftçi birlikteliğ̣”" formülü bu filmde de genel anlamıyla uygulanmıştır. Filmin atmosferi özellikle kullanılan kuklaların şekilleri ve canlandırlma tercihleri nedeniyle korkutucu bir şekilde çizilir ama şsılk açısından bir atmosfer yaratma gayesi göze çarpmaz. Kralın konuşamaması ve konuşma yapmak istediğinde bir pikap yardımıla playback yapması da onun acziyetini gösterme açısından önemli bir detaydır. Benzer bir gönderme de savaş sırasında rahibin bir sandığa girerek saklandığ sahnedir. Böylece filmin dinle ve din adamlarıla olan bağlantısı da bu kısa detayla özetlenir.

\section{Sonuç}

Sovyetler Birliği, ilk kuruluş yıllarından itibaren sinemayı önemsemiş, kendi ideolojisini sinemayı kullanarak yaymaya ve böylece kalıcı bir yönetim anlayışı oluşturmaya çalışmışıtır. Bu anlayış sadece politik bir tavır için yapılmamış, milliyetçi ve faydacı bir tavır da güdülerek başta yerel halk hikâyeleri, masallar, mitler olmak üzere pek çok türde eser üretilmiştir. Bu doğrultuda Sovyetlerin özellikle kurmaca ve belgesel alanında ürettiği çalışmalar bilinse de animasyon alanında da yüzlerce film yapılmıştır. 1900'lü yılların başından itibaren üretilen bu animasyon filmler zaman zaman propaganda unsurları taşısa da eğitim öğretimden mizaha, reklamdan bilim kurgulara kadar oldukça geniş bir çerçevede hazırlanmıştır. Daha çok kurmaca ve belgesel filmlerin bilinmesi, Sovyet animasyonuna yönelik çok fazla çalışma olmaması bazı nedenlere bağlanabilir. Bunun başlıca nedeni filmlerin Sovyetler Birliği arşivlerinin dışına uzun yllar çıkamaması ve insanlara ulaştırılamamasıdır. Bu animasyonların çoğundan ancak Sovyetler Birliği’nin dağılmasıyla birlikte arşivler açıllınca haberdar olunur ve filmlere 1990'l yılların sonlarına doğru çıkarılan DVD'ler sayesinde ulaşılmaya başlanır. Böylece devletin resmi animasyon stüdyosu olan Soyuzmultfilm'in 1936'daki kuruluşundan 1991'de Sovyetler Birliği'nin dağılmasına kadarki süreçte bu stüdyoda 1400'e yakın film yapıldığı tespit edilmiştir. Aynı dönemde sadece resmi animasyon stüdyosunda değil, ülkenin başka yerlerinde de farklı amaçlarla filmler üreten stüdyolar açılmıştır. Ayrıca 1936'dan önce de farklı gruplar tarafindan oluşturulan onlarca film mevcuttur. Bu filmlerin bu kadar kısa süre önce ortaya çıkarılması, kendi ülkesinde bile bu kadar az bilinmesi ve üzerine bu kadar az çalışma yapılmış olması bu çalışmasının çıkış noktalarından biri olmuştur.

Çalışma kapsamında yapılan çıkarımlar doğrultusunda, animasyonlar üzerine çok fazla çalışma olmaması bazı nedenlere bağlanabilir. Bunlardan ilki arşiv sorunudur. Filmler için düzenli bir arşiv oluşturulmamış ve bu nedenle özellikle video görüntüleri bulunamayan bazı filmlerin bilgilerine ulaşılamamıştır. $\mathrm{Bu}$ doğrultudaki çalışmalar 2000’li yıllardan sonra yapılmış ve iki önemli kaynak oluşturulmuştur. Bunlardan ilki Sergey Kapkov'un 2006 yılında Rusça olarak hazırladığı Yerel Animasyon Ansiklopedisi (Entsiklopediya otechestvennoy mul'tiplikatsii)'dir. İkinci kaynak da gene Kapkov'un baş editör olarak yer aldığı ve Rusya Federasyonu Basın ve Kitle İletişim Araçları Federal Ajansı tarafından da desteklenen Animator.ru animasyon veritabanıdır. Bu iki kaynaktan ulaşılamayan bazı bilgilere IMDb (Internet Movie Database), KinoPoisk, mults.info ve Kino-Teatr sinema veritabanları üzerinden de ulaşılabilir. Arşivleme konusundaki sorunlar, çeşitli tarihsel olaylar nedeniyle arşivlerin taşınmasına ya da 
yok olmasına da bağlanabilir. Ayrıca özellikle propaganda filmlerinin günlük siyaset akışında güncelliğini yitirmesi, dönemlik etkiler ya da işlevsel kaygılar için üretilmesi veya o dönem ya da sonrası için tehlikeli bir materyale dönüşmesi filmlerin saklanma durumunu değiştirmiş olabilir. Özellikle Soyuzmultfilm dönemi öncesindeki filmlerin farklı yer ve gruplar tarafindan oluşturulması da gene bulunamama sebepleri olarak gösterilebilir. Filmlerin hedef kitlesinin kendi halkı olması ve yurtdısına gönderilmemesi de filmlerin kaybolma nedenleri arasında düşünülebilir.

Çalışmadan görüldüğü üzere filmlerin anlattığı dönemi yansıtan belgeler olduğu çıkarımı yapılabilir. Hatta animasyonun metaforik ve hayal gücünü yansitma yeteneğinin kurmaca ve belgesel anlatıya göre daha fazla olmasının, toplumda oluşan kültürel hafızaya daha kapsamlı bir katkı yapmasını sağladığ1 söylenebilir. Ayrıca Rus kültüründe yer alan ikonaların kullanımı, Rus avangardı, illüstratif posterlerin yaygınlığı, kukla sanatının gelişmesi gibi nedenlerin de animasyonun çalışma alanını ve halk nezdinde kabul edilebilirliğini Sovyetler Birliği’nde güçlendirmiştir. Bu nedenle, bu çalışmadan yaklaşık yetmiş yılllk bir süreçte faaliyetini sürdüren ve sistemli bir mekanizmanın ürünü olarak içinde bulunduğu siyasal ideolojinin etkilerini ve yansımalarını gösteren Sovyet animasyon sinemasının Sovyetlerin siyasal tarihini ve toplumsal kültürünü yansıtan bir çeşit kültürel hafıza oluşturduğu çıkarımı rahatlıkla yapilabilir.

Çalışma kapsamında da görüldüğ̈ üzere Türkiye'de Sovyet animasyonlanı üzerine yapılan çalışma sayısı oldukça azdır. Türkçe literatürde Sovyet animasyonlarına yönelik neredeyse hiç kaynak olmamasından dolayı alana katkı sağlamak amacıyla ağırlıklı olarak Rusça ve İngilizce kaynaklar derlenmiş, içerikler incelenmiş, bu kaynaklar üzerinden genel bir bakış oluşturularak betimleyici bir analiz yapilmıştır. Sovyetlerin sinemayla ilişkisinin ve bağının anlatıldığı ilk kısmın ardından Sovyet animasyonlarının 1900’lerin başındaki ilk örneklerinden Sovyetler Birliği’nin yikılışına kadarki döneme kadar olan filmler incelenmiştir. Makalenin amaçlarından biri de bu alanda çalışmak isteyen akademisyenleri teşvik ederek onlara yardımcı olacak genel bir tarihsel anlatı sunmak ve yardımcı bir literatür özeti oluşturmaktır.

\section{Etik Beyan}

"Soryet Animasyon Taribine Genel Bir Bakış" başlıklı çalışmanın yazım sürecinde bilimsel kurallara, etik ve alınt1 kurallarına uyulmuş; toplanan veriler üzerinde herhangi bir tahrifat yapılmamış ve bu çalışma herhangi başka bir akademik yayın ortamına değerlendirme için gönderilmemiştir. Bu araştırma doküman incelemesine dayalı olarak yapıldığından etik kurul kararı zorunluluğu bulunmamaktadır.

\section{Kaynakça}

Alimova, S. (1997). Kinoteatr moyego detstva. Iskusstvo Kino, 8.

Amidi, A. (2006). Cartoon modern: style and design in fifties animation. San Francisco: Chronicle Books.

Animator.ru. Baza dannykh animatsii. http:/ / www.animator.ru/db/?p=films\&year=1912.

Balina, M. \& Beumers, B. (2015). To catch up and overtake Disney?: Soviet and Post-Soviet fairy-tale films. Zipes, J.; Greenhill, P. \& Magnus-Johnston, K. (Ed.). Fairy-tale films beyond Disney. New York: Routledge.

Bendazzi, G. (2015). Animation: a world history: volume II: the birth of a style - the three markets. Routledge.

Bendazzi, G. (1995). Cartoons: one hundred years of cinema animation. Indiana University Press.

Bocharov, V. (Producer). (2004). A belated premiere, Rusya: Gosfilmfond Rossiyskoy Federatsii.

Borodin, G. (2006). Soyuzmul'tfil'm: nenapisannaya istoriya. Kinovedcheskiye Zapiski, 80. http://www.kinozapiski.ru/ru/article/sendvalues/866.

Cavalier, S. (2011). The world history of animation. Berkeley: University of California Press.

Cavendish, P. (2019). The political imperative of color: Stalin, Disney, and the Soviet pursuit of color film, $1931-45$. The Russian Review, 78, 569-594.

Eisenstein, S. M. (1982). Film essays and a lecture, New Jersey: Princeton University Press.

Fadina, N. (2016). Fairytale women: gender politics in Soviet and Post-Soviet animated adaptations of Russian national fairytales (Doctor of philosophy). University of Bedfordshire: Research School for Media, Arts and Performance.

Faraday, G. (2000). Revolt of the filmmakers: the struggle for artistic autonomy and the fall of the Soviet film industry. University Park: Pennsylvania State University Press.

Georgievna, C. M. (2013). Metody, sposoby i priyemy sovetskoy propagandy v 1920-30-ye Gg. Xx V. Teoriya I Praktika Obshchestvennogo Razvitiya, 4, 181-183.

Ivanov-Vano, I. (2006). Ekler - za i protiv: Stenogramma doklada Primeneniye eklernogo metoda v proizvodstve risovannykh fil'mov. Kinovedcheskiye Zapiski, 80. http://www.kinozapiski.ru/ru/article/sendvalues/868.

Ivanov-Vano, I. (1950). Risovannyy fil'm. Moskva: Goskinoizdat.

İnceoğlu, Ç. (2013). Sovyet propaganda animasyonlarında Batı ve Batılı imgesi. Galatasaray Üniversitesi İletişim Dergisi, 19, 23-40.

Karaganov, A. S. (2009). Edebiyat ve sinemada yaşayan Lenin. (İ. Yerguz, Çeviri). İstanbul: Sel Yayıncılık. 
Kenez, P. (1996). Soviet film under Stalin. Nowell-Smith, G. (Ed.), The Oxford history of world cinema. Oxford University Press.

Khitruk, F. (1997). Kinoteatr moyego detstva. Iskusstvo Kino, 8.

Leving, Y. (2008). “Kto-to tam vse-taki yest...": Vinni-Pukh i novaya animatsionnaya estetika. Kukulin, I.; Lipovetsky, M. \& Mayofis, M. (Ed.). Vesolyye chelovechki: Kul'turnyye geroi sovetskogo detstva. Novoye Literaturnoye Obozreniye.

Lozhkov, D. V. (2013). Rol' propagandy v Sovetskom Soyuze po probleme formirovaniya obshchestvennogo mneniya po voprosam sovetsko-amerikanskikh otnosheniy v 1970-ye gody. Gosudarstvennoye Upravleniye Elektronnyy Vestnik, 38, 189-200.

Moritz, W. (1996). Ladislas Starewitch. Nowell-Smith, G. (Ed.), The Oxford history of world cinema. Oxford University Press.

Nevezhin, V. A. (2007). “Yesli zavtra v pokhod...": podgotovka k voyne i ideologicheskaya propaganda v 30-kh-40-kh godakh. Moskva: Yauza Eksmo.

Nowell-Smith, G. (1996). Socialism, fascism, and democracy. Nowell-Smith, G. (Ed.), The Oxford bistory of world cinema. Oxford University Press.

Nussinova, N. (1996). The Soviet Union and the Russian emigres. Nowell-Smith, G. (Ed.), The Oxford history of world cinema. Oxford University Press.

Paletz, G. M. (2001). Socialist realism. Pearson, R. E. \& Simpson, P. (Ed.), Critical dictionary of film and television theory. London and New York: Routledge.

Palumbo, J. (2018, September 24). How Cheburashka, the 'Soviet Mickey Mouse', achieved international fame. CNN. https://edition.cnn.com/style/article/cheburashka-soviet-mickey-mouse/index.html.

Pikkov, Ü. (2016). On the topics and style of Soviet animated films. Baltic Screen Media Review, 4, 16-37.

Polyakov, Y. A. (1967). Istoriya SSSR s drevneyshikh vremen do nashikh dney. Moskva: Izdatel'stvo "Nauka".

Reeves, N. (1999). The power of film propaganda: myth or reality?. London, New York: Continuum.

Romashova, M. V. (2011). Ot istorii animatsii k istorii detstva v Sssr: postanovka problemy. Vestnik Permskogo Universiteta: Istoriya, 3, 114-119.

Rotha, P. (1930). The film till now a survey of the cinema. London: Jonathan Cape Thirty Bedford Square.

Russell, M. (2009). Soviet montage cinema as propaganda and politic rhetoric (Doctor of philosophy). The University of Edinburgh.

Ryabov, O. V. (2018). Kak khorosho, chto nayavu YA Ne V Amerike zhivu!: obraz Ssha v gendernom diskurse Sovetskoy mul'tiplikatsii (1946-1963). Zhenshchina V Rossiyskom Obshchestve, 2, 89-103.

Sawicki, M. (2010). Animating with stop motion pro. Oxon: Taylor \& Francis.

Taylor, R. (1998). Film propaganda: Soviet Russia and Nazi Germany. New York: I. B. Tauris.

Taylor, R. (1979). The politics of Soviet cinema 1917-1929. Cambridge: Cambridge University Press.

Trotsky, L. (1986). Problems of everyday life. New York: Monad Press.

Tsentral'nyy Komitet. (1949, March 1). Plan meropriyatiya po usileniyu antiamerikanskoy propagandy na blizhaysheye vremya. https://www.alexanderyakovlev.org/fond/issues-doc/69577.

Vincenti, G. (1993). Sinemann yür yalı. (E. Ayça, Çeviri). İstanbul: Evrensel Kültür Kitaplı̆̆1.

Yuriyu Norshteynu dali yaponskiy orden. (2004, November 3). BBC. http://news.bbc.co.uk/hi/russian/entertainment/newsid_3977000/3977625.stm.

\section{EXTENDED ABSTRACT}

Since the beginning years of its establishment, the Soviet Union has attached exceptional significance to the cinema, endeavored to expand its ideology using it, and aimed to build a permanent administration strategy. This approach was for a political attitude and a nationalist and utilitarian perspective; many kinds of works were produced, essentially local folk stories, fairy tales, and myths. Even though the work produced by the Soviets in fiction and documentary is known, hundreds of movies have been created in animation. Although these animated films produced since the early 1900s have propaganda factors from time to time, they have been prepared in a reasonably comprehensive framework, from education to humor, from advertising to science fiction. The fact that more fiction and documentary films are acknowledged, the absence of adequate research on Soviet animation, can be attributed. The principal reason was that the movies could not go outside the archives of the Soviet Union for several years and could not be delivered to the people. Most of these animations are only identified when the archives are opened with the destruction of the Soviet Union, and the films are available thanks to DVDs released in the late 1990s. Consequently, from the institution of Soyuzmultfilm, the official animation studio of the state, in 1936 until the dissolution of the Soviet Union in 1991, it was determined that close to 1,400 films were made in this studio. In the same period, studios creating movies for several objects were opened not only in the official animation studio but also in other parts of the country; besides, dozens of films were created by different groups before 1936. One of the starting points of this study is that these movies have been unearthed so lately, and so little research has been done on them. 
According to the inferences made within the study's scope, the lack of sufficient investigation on animations can be related to some understandings. The first was the archive problem. A regular archive of films has not been formed, and hence knowledge about some movies, particularly those whose video footage cannot be found, has not been available. Studies in this direction were conducted after the 2000s, and two critical resources were created. The first is the Encyclopedia of Local Animation (Entsiklopediya Otechestvennoy Mul'tiplikatsii), which Sergey Kapkov published in Russian in 2006. The second source is the animation database Animator.ru, with Kapkov as chief editor and supported by the Federal Agency for Press and Mass Media of the Russian Federation. Some information that cannot be accessed from these two sources can also be obtained through IMDb (Internet Movie Database), KinoPoisk, mults.info, and Kino-Teatr cinema databases. Difficulties with archiving can also be associated with the relocation or destruction of archives due to various historical events. Furthermore, the fact that propaganda films are out of date in the daily political flow, produced for periodic consequences or functional interests, or turned into serious material for that period or later may have changed the condition of storing the films. The production of movies before the Soyuzmultfilm period by other organizations can be registered as the reasons for not being discovered again. The films' target audience is their people, and not being sent abroad can be considered among the causes for the films' disappearance.

As can be observed from the research, it can be inferred that documents reflect the time in which the movies were produced. It can even be stated that animation's capacity to exhibit metaphorically and imagination is more excellent than fiction and documentary narrative, making a more comprehensive contribution to society's cultural consciousness. Besides, the use of icons in Russian culture, the Russian avant-garde, the prevalence of illustrative posters, and the development of puppet art strengthened the field of animation and its acceptability to the public in the Soviet Union. Accordingly, from this study, it can be clearly deduced that Soviet animation cinema, which has been working for approximately seventy years and presents the outcomes and reflections of the political ideology in which it is located as an output of a systematic mechanism, constitutes a kind of cultural memory that indicates the political history and social culture of the Soviets.

As can be understood from the study's scope, the number of investigations on Soviet animations in Turkey is comparatively inadequate. Since there is nearly no source for Soviet animations in the Turkish literature, chiefly Russian and English sources were compiled to contribute to the field, the contents were examined, and a descriptive analysis was made by creating an overview over these references. After the first part of the connection of the Soviets with cinema, movies from the earliest instances of Soviet animations in the beginning 1900s to the fall of the Soviet Union were analyzed. One of the articles' aims is to implement a general historical narrative that will help academics who want to work in this field and contribute a valuable research review. 